\title{
Staging national identities in contemporary Estonian theatre and film
}

\author{
Ester Võsu, Alo Joosepson \\ Department of Semiotics, University of Tartu \\ Tiigi str. 78, 50410 Tartu, Estonia \\ e-mails: ester.vosu@ut.ee, alo.joosepson@mail.ee
}

\begin{abstract}
This paper focuses on the ways in which national identities are staged in recent film and theatre productions in Estonia. We want to complement the prevalent approaches to nationality (Anderson 1983; Gellner 1983; Bhabha 1990), where the role of theatre and film as modellers of national identity are undervalued. National identity is a complex term that presupposes some clarification, which we gave by describing its dynamics today; its relation to ethnic identity, a thread between the lived and declared national identities, and the relevance of culture-based national identity. Herein we consider the concept of staging to have two implications: (1) as an aesthetic term it incorporates an artistic process, comprising several devices and levels; (2) as a concept in cultural theory it describes cultural processes in which something is set on stage for public reflection. Accordingly, in our analysis we considered national identities in theatre and film stagings in both senses. The results of our analyses demonstrated that our hypothesis about emerging new national identities in Estonia was valid, though deconstructed and hybrid national identities are not exactly and absolutely new types of identities but rather strategies of creating space for new identities to develop. A deconstructed national identity refers to the state of high self-reflexivity in which the existing elements of national identity are re-examined, recontextualised and re-evaluated. Further, a hybrid national identity demonstrates the diversity and coexistence of the components of national identity. Both strategies of staging are characteristic of the transformation of national identities, confirming that a single homogenous staging of national identity seems to be replaced by bringing multiple new self-models on stage.
\end{abstract}


Artists help to create and reproduce the very fabric of national communities to which they belong, and thereby disseminate and perpetuate the idea of the nation itself, its history, development and destiny. Anthony D. Smith (2000: 57)

Scripts and roles, stage management, directing, improvisation and reflexivity - all function as parameters of national identity

In social sciences and humanities today, 'identity' is a complex term, evoking numerous definitions and interpretations. Literally signifying sameness in qualities or conditions between different entities, its diverse contemporary uses make it impossible to find a single satisfying formulation for the concept. In this sort of a situation 'identity' is described through various characteristics, such as constructedness, dynamics, processuality, multiplicity, fragmentation, etc. This contemporary comprehension of the fluidity of identity, however, does not mean that all coherence is lost, instead it underlines the fact that the latter is continually reproduced.

By focusing on the concept of 'national identity', we support the idea that national cultures and identities are not disappearing from the globalizing postmodern world, but instead resist the process of selfdestructive fragmentation. In post-soviet countries, including Estonia, the rise of nationality and the need to redefine national identity seems to be a sign of the cultural logic of post-socialism (Annus 2000a: 769780; Binder et al. 2001: 7-9). National identity apparently does not vanish in the European Union nor in other international political and economic associations. Instead, the subject of the national undergoes changes and needs to be redefined in complex systems of contemporary socio-cultural relationships, where identities are processes that "weave together" multiple elements such as "fragments of discourses and images, spaces and times, things and people" (Edensor 2002: 2930). Finally, it is inadequate to talk about a single national identity today, but of plural national identities; and, of course, national identity in its own turn should be considered within the pattern of other cultural and personal identities of the (post)modern human being. 


\section{National identities in change}

Although recent discussions about the changing nature and approaches to national identity have concerned themselves with aspects of popular culture, such as tourism or sports, as well as with less visible forms of "banal" or "popular" nationalism (Edensor 2002; Pretes 2003; Porter, Smith 2004; Billig 1995), we prefer to stay within the more traditional genres of "high" culture, such as theatre and film. First, because we think that distinguished works on cultural nationalism (Anderson 1983; Gellner 1983; Bhabha 1990) have underestimated the role of theatre and film in the processes by which the various forms of cultural expression have been instrumental in helping to construct notions of national identity. In addition, theatre and film as (re)creators of national identity in Estonia have not heretofore been sufficiently studied. Second, theatre and film do not function only as high-culture institutions subsidised and thereby controlled by the state, but because of their communal creation and reception they also serve as public and popular forums for reflecting, discussing and interpreting national identities. One could say that theatre as well as film facilitate the revelation and exhibition of latent practices and lived identities.

Several criteria can be advanced that distinguish one nation from another (e.g. membership of an ethnic group, shared language, shared culture, shared values, etc.). National identity refers both to these defining criteria as well as to the sense of belonging to a particular group. When distinguishing national from ethnic identities ${ }^{1}$, one of their most conspicuous discrepancies is the heterogeneous nature of ethnic culture, whereas national cultures attempt to bring different ethnic traditions under the denominator of one nation ${ }^{2}$. Indeed, it is vitally important for every nation to develop a sense of integrity and to recognize and acknowledge the boundaries that differentiate it from other national cultures. Ethnic and/or national symbols provide good evidence in the process of dissociating "us" from "them" (Edensor 2002: 8) and here both film and theatre have "offered a particularly effective means of conveying notions what is national and what is

For the attributes that distinguish ethnic and national identity, see Smith 1991: $14,21$.

2 On the other hand, national cultures today are themselves part of a multifarious world that contrasts with the global tendencies of homogenization. 
alien" by considering their "rhetorical and semiotic features" (Wilmer 2002: 1). In the spatial dimension, identity manifests itself in the tension between the poles of the opposition in-out and its variants (me-the other, we-the others), revealing the inherently dialogic nature of identity. In the temporal dimension, identity is about a subject being able to change and remain the same simultaneously (cf. Lotman 1992: 7-8), making the existence of conflicting representations of national identity possible. Thus one can say that in addition to retaining its sameness (traditional core), the capacity to change makes national identity dynamic and thereby viable in the contemporary cultural environment.

Due to its homogenous nature the formation of national culture is mostly based on normative self-models that fit the mental image of national culture in which various phenomena that unfold in the actual cultural process of a community are excluded. Such a unified declared collective identity explicit in self-models of the nation often conflicts with the implicit, lived identities experienced and perceived in the actuality of the cultural everyday life (Edensor 2002; Friedman 1994; Lotman 1990: 128-129; Kotov 2005: 185-188). Therefore a certain tension between the declared and lived identity inevitably remains, "as lived identity is always project, not settled accomplishment" (Calhoun 1998: 27), but in order to sustain and communicate national identity some stable and typical elements in it are inevitable. In Estonia, the conflict between declared and lived identities arises mainly from a tradition that rejects ethnically foreign (primarily German and Russian) and socially unaccepted "others" (e.g. numerous socially challenged rural inhabitants) from the image of national identity and only recently has began to include them. At the same time, lived identities in Estonia have developed within a manifold of alien influences and at this point both the recent disposition towards the deconstruction of traditional self-models and the acceptance of hybridity as an inherent constituent of Estonian national identity are examples of renewed self-models.

It is important to stress here that similarly to many other small nations, Estonian national identity has been primarily culture-based, mostly concerned with engaging in our ethnic heritage (language; values, symbols, myths, narratives; music, folklore, literature; clothing; festivities, etc.) and the creation of new efforts in various cultural practices. Cultural nationalism differs from political 
nationalism - whereas the latter has its roots in the modern legalrational society, the former is first and foremost

a movement of moral regeneration which seeks to reunite the different aspects of the nation - traditional and modern, agricultural and industry, science and religion - by returning to the creative life-principle of the nation. Its proponents are not politicians or legislators, but are above all historical scholars and artists who form cultural and academic societies, designed to recover this creative force in all its dimensions with versimilitude and project it to the members of the nation. (Hutchinson 1987: 14 - cited in Mäkinen et al. 2001: $57-58)$

For this reason the key role played by intellectuals (writers, historians, artists, scholars) is often stressed in building national cultures. Creators of national theatre and film productions are part of the group of nation-designers, being members of the very same national community, embodying the same identities, and offering manifestations of these identities in their works, although often unintentionally. Directors may stage particular versions of national identities, suggesting opportunities for identification, but it is the audience who decides whether these models will function as accepted self-models or not. Although the conceptual language of self-models of a nation is usually formed by the elite, national cultural hegemony is not simply an asymmetric process, enforced by cultural leaders to whom the masses are subjected, instead "it must be achieved, must offer plausible points of identification" (Edensor 2002: 8).

We have chosen the insider's viewpoint for analysing some of the new self-models and self-representations of Estonians in contemporary theatre and film productions. Our paper focuses on the ways in which national identities are staged in contemporary film and theatre productions, by observing the effects that appear when the established canon encounters artistic interpretation; furthermore, we examine how the emergence of new national identities might be associated with the changing self-models among present-day Estonians. 


\section{Staging national identity}

The term staging is a relatively uncommon noun in English, and in theatrical discourse the term production is usually used instead. However, the latter has connotations that hinder its use as an analytic metaphor, therefore we find staging to be more appropriate for discussing the development of national identities. For instance, the German and French equivalents, Inszenierung and mise-en-scène, both originating form theatre practice, are today used as critical analogies for describing and analyzing various cultural phenomena (Willems, Jurga 1998; Müller-Doohm, Neumann-Braun 1995; Pavis 1992). In fact, differences between the three terms are unsubstantial, as they all refer to (a) putting a play on a stage (by a director) as well as (b) producing or organizing something for a public viewing. Below, we will concentrate both on aesthetic as well as culture-theoretic meanings of the concept.

\subsection{Staging as a cultural concept}

If we consider culture as staging, two implications of the concept for contemporary theoretical discourses may be distinguished. One dominant viewpoint associates staging of culture with everything that is unauthentic, insincere, simulated and false. The other approach, in similar manner, sees staging mainly as the activity of certain ideologically-motivated figures in politics, media etc., with the purpose of manipulating people to think and act in certain ways ${ }^{3}$. A third alternative, suggested by Erika Fischer-Lichte (2004: 17-18) conceives staging primarily as a general "descriptive concept" in cultural theory that does not necessarily contain value judgments. This latter sense, in conjunction with a semiotic perspective, sees staging as incorporating three actions - setting something/somebody on a stage, performing something/somebody on a stage, and perceiving something set on stage as a signifying model (see Eco 1990: 104-105).

\footnotetext{
3 From this aspect, the idea of staging the nation involves staging it for outsiders (e.g. tourists) or observing it from an external point of view (i.e. staging "the other" for "us"); presenting the nation in international events or in the media, and the manipulation of the people by local authorities or elites.
} 
Therefore, the study of stagings and performances ${ }^{4}$ of a culture refers to a "a critical way of grasping how persons choose to present themselves, how they construct their identity, and ultimately how they embody, reflect, and construct their culture". (Fine, Speer 1992: $10-$ cited in Ruby 2000: 245)

Thus, we cannot consider staging as a simple and purely asymmetrical and unidirectional ideological form of communication, where actors as well as spectators are manipulated by an omnipotent director. Culture is a collective staging, formed by the cooperation of various intentions; to a certain extent, everyone participates in the staging of a culture, in the processes of rehearsal, performance or in the reception.

\subsection{Staging as an aesthetic concept}

Although theatre is a live and film a technologically mediated art form, and their modes of representation differ in many respects, we consider staging to be the uniting concept that refers to the strategies and aspects that are similar in both arts. Film and theatre actually share various common sign systems, such as acting, costumes, props, design, make-up, music, dialogue, etc. Martin Esslin (1987: 23-38) defines fictionality, acting, spectatorship, and synthesis of various arts as characteristics that are inherent in all dramatic media. Both theatre and film derive from "the mimesis of human interaction through its embodiment by human beings assuming the identities of (fictional or real) human beings and presenting this interaction to an audience as

\footnotetext{
4 The concepts performance and staging often intermingle in critical discourse, although the former is usually preferred. However, a distinction between them is necessary in the present context, as they stress different aspects of a cultural process: staging indicates the imaginary and performance points to the material, manifested dimension. Staging is not a direct perceivable empirical object, but above all "an object of knowledge, a network of associations or relationships uniting the different stage materials into signifying systems, created both by production (the actors, the director, the stage in general) and reception (the spectators). [...] Mise-en-scene as structural system exists only when received and reconstructed by a spectator from the production. [...] The aim is not one of reconstructing the intentions of the director, but of understanding, as a spectator, the system elaborated by those responsible for the production" (Pavis 1992: 25). The study of cultural performances is inevitably related with the analysis of staging - the principles that frame and model the former both in the processes of rehearsal, enactment and reception.
} 
though it was happening at that very moment before their own eyes" (Esslin 1987: 23-38). Although the devices may differ, the creation and exchange, representation, and evaluation of identities are always present in theatre and film. In the following pages we will discuss six primary meaning-generating choices of staging that we will proceed from later on, in the analysis of four specific stagings in theatrical and film productions.

Staging evolves from two parallel sources: the individual author's/ authors' creation and from a particular cultural context. Often a written play or some other literary text is the starting point from which every director proceeds to make his or her concretisations. The very choice of text itself is the first step in the staging process - whether it is an international or national classic, a contemporary unfamiliar foreign author, a local infamous celebrity, etc. Choosing the text, or in a broader sense, material for the scenario, is therefore not a neutral but an evaluative decision. Reception today is not viewed as an isolated act. The intertextual world of other cultural texts and previous interpretations of the same text form an intermedial textual network which begins to influence the processes of ongoing and upcoming stagings. Furthermore,

the same texts appear, more or less lightly adapted, in all the dramatic media: many leading actors tend to be prominent in all of them; many of the best directors and designers work in theatre, film and television and can switch from one to the other without undue difficulty. (Esslin 1987: 34-35) ${ }^{5}$

Other important aspects that determine the choice of signs and codes and refer to the intentions of the creators with respect to future reception are the choice of a viewpoint (from "outside" or "inside", for "us" or for "the others") and the genre (comedy, drama, etc.) of a production. Dominant sign systems and the relations between them are in the heart of a staging as a fictional world; the staging space and the actors being of utmost importance here.

The actor forms the core of performing arts and is a major element for the spectator to identify with in the theatrical/film production. Casting as the process of choosing the actors to perform the roles therefore involves fundamental questions such as - who will play the

5 This is especially true of the conditions of cultural production in Estonia, where human resources are rather limited. 
main roles and why, how will they play these roles (acting style, appearance, bodily movements, etc.), what is the relationship between the actor's identity and the character he or she embodies?

In the contemporary sense, stage is not just mere setting and decorations, but instead all spatial circumstances and characteristics that influence and shape the movements of the actors, as well as the relationships between the fictional characters and events. Performance places are rarely as neutral as an empty stage or a black-box would be; they are always already saturated with meanings and memories. The objects displayed in stage space often acquire a symbolic and an indexical meaning besides the iconic one.

Finally, from each staging a general conception, style, idea(s) and theme(s) hatch that in turn make it possible to return the aesthetic staging back to a wider cultural context and thereby the understanding of certain aspects of culture (e.g. national identity) may be cast in a new light. ${ }^{6}$

\subsection{Staging national identity}

The concept of staging is equally useful for focusing on a particular aspect of culture, such as national culture. To a certain extent, national identity is always a staging, although its concepts and representations might differ inside and outside national culture. National identity as a staging evolves from different choices of cultural signs (from national/ethnic heritage as well as from contemporary culture; what symbols, values, ideas become significant; who are the main characters/heroes; what is the setting for a particular staging, etc.) and their combinations, as well as from their "ostension" (Eco 1990: 103), the way they are put on public display and meant to stand for an entire class of objects. Staging of a nation is first and foremost

[...] the analysis of symbolic communication that plays a central role in the apprehension of the collective concept of national identity. [...] Hence the central question is: how the semantics of the national becomes translated and reset in concrete cultural representation and mobilization strategies. Nations

$6 \quad$ This process of interaction between an artistic model and the world - reality as reinterpreted in light of artwork - is described in more detail by Juri Lotman (1967). 
are "set on stage" and thereby into the space of experiencing the community as "us" [...]. (Binder et al. 2001: 10)

Although in the above quote the staging of national identity is underlined as an important strategy for a community to achieve public agreement about who they are, we accordingly want to emphasize the dialogic nature of the process of self-staging (Selbstinszenierung). Whereas the processes and strategies of self-staging are better explicated in theories of social identity of individuals and minority groups (e.g., subcultures) associated with the public presentation of self, social roles and lifestyles (see Früchtl, Zimmermann 2001: 10 18), we consider it appropriate to pay attention to self-staging in the context of national identity. As indicated above, national identity concerns both certain characteristics and a sense of belonging to a certain group. Proceeding from the Canadian sociologist Erving Goffman (1959) and Russian sociologist Leonid Ionin (1996), the phases of staging in culture are described as particularly characteristic of societies in transformation (such as Estonia and other post-Soviet countries), where the need to stage new identities is urgent. The process of self-staging can accordingly be divided into two phases: (1) rehearsing the new identity (Goffman's "backstage"), and (2) acquiring and fixing the new identity by performing it (Goffman's "frontstage"). In the second phase the reception of the new identity is equally important - the conceptual base and the ways by which a group will be "known by certain others" (cf. Cohen 1993: 195) is formed here. In conclusion, both staging the self in the autocommunication of a national culture as well as the process of dialogic communication with other cultures are needed to establish a developed model of national identity.

Since national identities are always created collectively, it is difficult to pinpoint their precise "director". Cultural stagings are embodied practices where the borders between the collectively established "scripts" and individual realizations are not always evident.

7 "Bewust sprechen wir von der "Inszenierung" des Nationalen und weisen damit der Analyse symbolisher Vermittlungsformen eine zentrale Rolle für das Verständnis nationaler kollektiver Identitätskonzepte zu. [...] Eine zentrale Frage war daher, wie die Semantiken des Nationalen in konkrete kulturelle Repräsentations- und Mobilisierungsstrategien übersetzt bzw. umgesetzt warden. Nationales wird "in Szene Gesetzt" und dadurch zum Raum für die Erfahrung von WirGemeinschaften [...]" (Binder et al. 2001: 10). 
We want to lend our support to the approach that takes agency into active consideration and sees staging of a nation not as something external to the people, but as something that unfolds between the interaction of the people (Edensor 2002; Thompson 2001). Unlike in theatre, where explicit individual authorship is valued, the strength of staging a national identity lies in its collectivity and heterogeneity the more coherent the staging of a national identity and the more recognizable the position of the director(s), the more ideologically manipulated and asymmetric is the communication of identity.

At this point we would like to remind the importance of differentiating between the political, state-based national identity and cultural identity; we would also like to add the consumable national identity to the list. In the contemporary world, staging a nation is more and more often associated with the aim of branding a nation in the global market (especially for touristic purposes), where often an ideal national identity is staged, involving elements such as "generic landscapes and attractions, and promoting particular sites and events" (Edensor 2002: 85). Consumable national identities are often staged in theatre as well as in film productions that are targeted at international audiences. Frequently, the official identity of a nation staged by governmental or business authorities conflicts with the usually much more heterogeneous ${ }^{8}$ popular stagings and representations of a nation. Some of the significant features of national identity may nevertheless coincide (e.g. in Estonia, the national flag, the national anthem, symbolic landscapes). Accordingly, staging self for the others inevitably needs an auto-communicative phase, where various self-models are considered, analyzed and rehearsed.

8 Although the project Brand Estonia, realized between 2001-2002 and coordinated by Enterprise Estonia, wished to distance itself from presenting a new national identity, it still provoked a controversy in Estonia, since it was managed in an asymmetrical way and still touched several aspects of pre-existing national identities. The essential conflict of the project consisted of an ambition to create visual and textual representations that would simultaneously describe what Estonians are for themselves as well as how they are seen by the others. (See http://www.eas.ee/?id=12 .) See also footnote 25 . 


\subsection{Staging national identity in Estonian theatre and film}

The problem of representing national identity in theatre and film brings together both the aesthetic and cultural aspect of the concept of staging.

National identities are not just mental constructs, their formations and reproductions are still grounded in spatially and temporally rooted "material, performative and representational dimensions of everyday life" (Edensor 2002: 20). In other words, stagings operate through concrete and perceptible manifestations that should create preconditions for a common understanding of valid representations of national identity. (Although they may be differently accepted and interpreted among different groups in the same national community.)

Theatre and film productions can be considered as concrete selfrepresentations of national culture. Theatre and film reflect the reality of the culture in which it originates in a sense that it "depicts that reality and presents it in such a depiction" (Fischer-Lichte 1992: 10). Traditionally, theatre and film directors have actively participated in this "project of popular national representation and renewal". They have staged the "ideal of the nation and its historical myths, memories and symbols" mostly in a realistic mode of expression, executing it in "palpable, dynamic forms which are easily accessible to the mass of the 'national' membership" (Smith 2000: 48). The innovative potential of theatre and film in staging a nation must be especially stressed in the contemporary cultural situation. Today, national identities as cultural identities are not predominantly determined by the past, although their historical dimension is undeniable; they are undergoing a constant transformation. Present identities are "the different names we give to the different ways we are positioned by and position ourselves within, the narratives of the past" (Hall 1994: 394). The coexistence of different aesthetics and theatrical/film styles initiates and brings out new alternative strategies of positioning national identities, some of which may be ironic, grotesque, and parodic. The fondness by which such critical positions are adopted stands witness to the strong conventional core of national identity - the persistence of its mythical and archetypical elements that form the basis from which new identities and representations emerge.

Estonians have traditionally employed art culture for the purposes of creating coherence within an imagined community as well as for 
claiming political independence and for creating a feeling of resistance against alien occupying cultures. Drama was a powerful tool for awakening the people of the post-romantic period to a common heritage, and to oppose external political and cultural influences (Carlson 1994: 152). By first modelling themselves after Germans and later creating their own original plays and theatre societies, the Estonian cultural elite "awakened the nation" in the second half of the 19th century. ${ }^{9}$ During the Soviet occupation, a period of national crisis, theatre in particular functioned as "a political and ideological tool to help reconfigure the nation" (Wilmer 2002: 3); theatre could often fulfil the function of resistance better than film, because its "liveness" made it more difficult to be controlled by Soviet censorship and made it a substitute for the missing free broadcast media. Using a different medium, national film likewise functions as the creator of stagings of national identity through choosing

identifiable national narratives and myths, tradition of particular genres; conventions of acting and characterization (bodily and paralinguistic codes), signs and values carried by national stars, and finally, the audience for whom the film is meant (home, international). (Gledhill 2001 - cited in Edensor 2002: 143-144)

During the Soviet period, several admired comedies in Estonian film turned a number of local star-actors into "national heroes" (who were later identified with the roles they played) and excerpts from their dialogues became popular catch-phrases that still function to create a feel of community among Estonians. From the end of 1980s and 1990s, Estonian film has served as an important enlivener and reappraiser of national history, staging themes that could not be dealt with during the Soviet period. Today, art culture has lost its earlier function of resistance, although theatre and film still offer "symbolic stages where national identity can be dramatized, broadcasted, shared and reproduced" (Edensor 2002: 69).

Staging national culture in Estonian theatre and film is connected with the question about the relationship between political and cultural national identities. First, theatre in particular, but film as well,

9 The popularity of amateur theatre and theatre going today still testifies to the importance of this medium among Estonians. 
function as national cultural institutions that present certain views of a nation, influencing

the emergence of certain types of texts by legitimizing them and giving them a point of insertion in society. These institutions constitute the main part of the dominant system and ideology, and as such play a central role in the distribution and consumption of cultural texts. (de Toro 1988: 44)

In this sense, theatre as well as film have played an important role in Estonia as institutions of national culture. Second, as an effect of governmental subsidies, a tension between the official and hegemonic, and the alternative artistic interpretations of national identities seems to emerge. In practice, neither theatres nor films that get financial support are expected to make considerable profit themselves; national cultural institutions cannot be strictly market oriented. It should be clarified, however, that in contemporary Estonia, the state of film is markedly different from the theatre system, and this definitely influences the position of film as a medium for representing national identities. Theatres in Estonia have been subsidised by the state from the 1920s onward (although they were turned into national institutions only after World War II) and as an institution theatre is still considered a crucial component of national culture. A poll analysing the consumption of culture by Estonians conducted in 2003 indicated that $53 \%$ of the inhabitants visit theatre at least once a year; the number is rather noteworthy, considering that the Estonian population is a mere 1.5 million. ${ }^{10}$ Although Estonian film also received state support during the first decade of independence, it soon lost it and remained in an unstable situation until becoming part of the heavily censored Soviet system of film production and distribution. This statecontrolled and financed system of studios and network of cinemas crumbled after the collapse of this political system. During the 1990s, Estonia as a developing state lacked resources to finance the local film industry, and consequently domestic film-making went to a decline. The Estonian Film Foundation, established by the government in 1997, is intended to create favourable conditions for the development of national film by financing the creation, production and distribution of professional national film. Nevertheless, the funds available are too limited for the creation of a sufficient number of films and thereby

10 See http://www.kul.ee/index.php?path=0x917\&sona=kultuuritarbimise. 
ensuring artistic development and diversity (e.g. between 2002 and 2003, the budget was 34,34 million EEK per year ${ }^{11}$ ). The fact that films from 1960s and 1970s still form a significant component of national identity and that Estonians prefer comedy ${ }^{12}$ both on stage and on screen indicates that staging of national themes should take this genre earnestly into consideration.

In conclusion, it is not so much the Estonian state that controls what is staged and how; rather, the genres, themes, styles, conceptions, devices, etc. are influenced by the rules of a liberal market economy and consumer preferences of contemporary theatre and filmgoers in Estonia. All in all, the directors still have possibilities to stage alternative, ironic, critical, parodic, etc. interpretations of national themes and characters. For the object of our analysis, we chose new stagings of national identity that deviate from the traditional four theatre productions and films from 2002-2003 whose identity strategies can be considered as deconstructed and hybrid. Only the first one of them "Estonian funeral" deals explicitly with Estonian national identity. In the other 3 stagings the question of national identity is implicit and its crucial role in the formation of the conceptual system of the staging has to be explicated through analysis.

\section{Deconstructed national identity}

To be able to deconstruct, one first has to realize that something is constructed. To specify which of the multiple meanings of the concept "deconstruction" is employed here, some references to classic definitions are necessary. Deconstruction started out as a label for a specific way of "reading" and criticizing philosophical texts, first initiated by Jacques Derrida, but the uses of the concept have proliferated during the past few decades (see Norris 2003: 134-135). For the purpose of our analysis we take as a starting point the widest categorisation of deconstruction as an "intellectual strategy" (Culler 1983: 85) that has significantly influenced the creation of the subsequently analysed theatre and film texts.

Identity as a mental construct relies extensively on hierarchical oppositions of differently valued categories (in-out, self-other, us-

11 See www.efsa.ee.

12 See http://www.kul.ee/index.php?path=0x917\&sona=kultuuritarbimise. 
them, now-before, normal-abnormal, city-countryside, etc.). In the present context, deconstruction does not directly refer to the reversal of the hierarchies in a Derridaean sense; instead, it opens up developmental perspectives for national identity, forcing one to acknowledge the constructedness of the prevailing identity, making it questionable and thereby creating space for the emergence of new identities. The dichotomous categories can be criticized and their repressive power can be decreased by inserting them into new contexts (for instance, artistic texts), where their inner contradictions and unjustified, arbitrary values become explicit. An important part of tracing this questioning is the critical examination of theatrical and filmic representations (more specifically, the key signifiers of Estonianness) that embody the conceptual oppositions.

Other strategies also exist that use different techniques for similar purposes, such as "demythologisation" or "demystification", as Roland Barthes (1957) has employed them to criticize the "naturalness" of secondary meanings of cultural signifiers. We prefer the term "deconstructed identity", since it refers to the whole complex domain of questioning national identity, which is not based solely on myths.

A parodic mode of textual production is one such deconstructive strategy, applied to stagings analysed later in this paper. Parody includes any cultural practices that provide a relatively polemical, allusive imitation of another cultural production or practice (Dentith 2000: 9). Humorous effect arises from the displacement of recognized textual elements into a new context, making them conflict with the expectations of the spectator. (A single film or theatre performance can simultaneously parody, that is imitate allusively and polemically, several other cultural texts or practices). Usually, this polemical moment urges the recipient to reconsider his/her reading of and attitude towards the parodied texts or practices, including the values and identities conveyed by them.

Deconstruction of national identity accordingly consists of a specific interpretation of canonical texts (e.g. presenting stereotypical self-models) of national culture that entails the dismantling of conceptual and hierarchical oppositions in those texts, bringing out the repressed and silenced aspects which, when explicit, render the text paradoxical, self-contradictory and thereby decrease its authority. This deconstruction does not necessarily have to be done "in a spirit of game-playing nihilist abandon and without the least concern for 
constructing a better alternative" (Norris 2003: 135). An ethically responsible deconstruction is possible.

It has been noted that in Estonia, a former socialist country, the essentialist concept of national identity is still preferred to constructivist approaches (Sevänen 2004: 50-51). This preference is prevalent mainly among the older generation of Estonian intellectuals, who have felt a crucial need to preserve the national past. However, during the 1990s, a younger generation of Estonian researchers has welcomed postmodern theories concerning the constructedness and mutability of identity, social reality and national community (Annus 2000b: 115-130; Viires 2004: 130-139). The postmodern perspective has influenced not only the critics but also the creators of artistic texts, encouraging them to deconstruct the commonly held perceptions of Estonianness that emphasize historical narratives, ethnic heritage, etc. in national identity.

\section{1. "Estonian Funeral"13}

"Estonian Funeral" ("Eesti matus") is based on a recent play by Andrus Kivirähk (2002), a writer of the younger generation, who has already achieved a cult status in Estonia today. He is prolific in a variety of genres, from newspaper columns and pamphlets to dramas and novels, as well as co-hosting a hilarious, socially critical radio talk show. For him, national history serves as fictional material for creating new fiction - tales and myths that (re)construct our popular national consciousness. The primary devices employed by Kivirähk are parody, irony and the grotesque, which he applies to national stereotypes and common clichés well known to most Estonians. "Estonian Funeral" is probably one of his most successful dramatic texts, with its excellent comic characters and, as with all good comedies, a bitterly serious dimension as well.

Although the dramatic situation - a funeral where various relatives meet again after a long separation - is one of the most viable archaic rituals in all cultures, the topics and problems that emerge in the present text are for the most part specifically related with Estonianness. This claim is grounded on the fact that "Estonian

13 Premiere: June 8th, 2002, Estonian Drama Theatre. Text: Andrus Kivirähk. Director: Priit Pedajas. Scenographer and costume designer: Pille Jänes. 
Funeral" is a parody of the epopee "Truth and Justice" ("Tõde ja õigus") by the most distinguished national writer Anton Hansen Tammsaare, who through his writings offered a model of national values for many generations of Estonians.

The staging in the Estonian Drama Theatre sets the play into a stylized backyard of the deceased grandfather's old farmhouse. The central element of the scanty stage design is a huge stack of firewood that functions on several levels, referring both to the practical and the symbolic. Firewood, especially in the countryside, but also for many urban dwellers, is still the main source for heating. Buying, chopping and piling firewood are familiar activities for most Estonians. These practices are also displayed on stage - the axe is a significant prop. The end of the stack disappears into distance, symbolising the neverending need to work in a farmhouse. In the scenography, the stack restricts the fictional world the audience can see - most of the action takes place in front of the stack and one can only guess as to what lies beyond. On the other hand, this is a place in a periphery, hidden form the neighbours' gazes, suitable for solving family problems or even a nice place for a garden party. Similarly, the location of Estonia in the European Union is comparable with the fictional place in the staging of "Estonian Funeral" - somewhere behind a stack of firewood.

The main theme both in the play and in the staging is a parodic representation of the Estonians' work ethic, powerfully described in the aforementioned novels by Tammsaare, something that is accepted at face value by most Estonians - "work hard and love will come". The most commonly accepted self-description states that Estonians are a laborious people and because of this they survived all difficulties in the past and are going to survive them in the future. "Estonian Funeral" shows us several different types of workaholics, who are created by using well-known cultural and theatrical stereotypes. Grotesque or freakish types are created by the costumes and make-up of the actors. The bodily shapes of some female characters are exaggerated, stressing the stereotypical figure of an Estonian mother who can support three children and a husband, who is either a duffer or a drunkard. In general, the characters and aesthetics of the staging embody the very essence of a popular comedy (e.g. situation comedy), resulting in tours to various different locations in Estonia and is a guarantee for full houses even today. However, in spite of the plenitude of comic situations and characters, the general message of 
"Estonian Funeral" is far from funny; quite the contrary, it is very tragic, but it replies to painful national memories with a liberating laughter. Critical reception has called it a refreshing "national therapy" that offers a possibility for comic distancing from the painful memories and taken-for-granted national values (Vellerand 2003: 137).

We can observe the older generation (mother and father) in "Estonian Funeral" who for most of the time live and work in town, but nevertheless do several farm jobs in their parents' household potato planting and harvesting, berry-picking and cooking jam, etc. At a first glance, the middle-aged businessman (uncle) with his careermaking wife are the exact opposites of mother and father, but in fact their labour-mania is just directed into other channels - office work till late hours. Even their holidays pass as hard work - from training to sailing and riding etc, etc. The majority of the characters form a group subjected to the protestant work ethic.

The protagonist and supposedly the alter ego of the playwright young Andres (Jan Uuspõld) - is an ambivalent character, who also performs the role of the antagonistic narrator. He argues against this deeply rooted workaholism and has a "geopathologic" (Chauduri 1995) relationship with his grandfather's farmstead. For his parents, this household is a locus of various obligations, for his uncle and his wife it is a pastoral area, a good place for a brief vacation. For young Andres, his topophobia stems from unpleasant childhood memories, when he was forced to work in this farm during summertime. The grandfather's old farmhouse becomes a symbol of national labourworship and repression. This place has lost its value for Andres and the only reasonable solution for him is to sell the house (cf. Chekhov's "Cherry Orchard"). For the characters of the older generation in "Estonian Funeral", the father's "home is the foundation of [their] identity as individuals and as members of a community"(Relph 1976: 39). Andres wants to escape his grandfather's farm, because he defines it as a "house" and not a "home" and believes that selling it helps to erase his memories and prevent him from becoming like his parents and relatives. Selling homesteads as a result of lifestyle changes is a painful problem for rural inhabitants in contemporary Estonia, especially in the western part of the country and the islands, where many households are inhabited by new owners from Finland or Sweden. Homogenous rural communities are decaying, most new- 
comers stay only for seasonal vacations. Declared national identities (e.g. Estonians - the hardworking farm people) are more stable and in this case they conflict with the real new lived identities.

\section{2. "The Old and the Bold Get on Their Feet"14}

The Estonian feature film with an international distribution title Made in Estonia (2003) is a parodic comedy (with elements of travesty, drag and slapstick humour) that aims to be funny and serious at the same time, having a tragicomic and also some bittersweet tonality in it. The original Estonian title — Vanad ja kobedad saavad jalad alla (a literal English translation could be "The Old and the Bold Get on Their Feet") - summarises the characters and the storyline in a nutshell.

"The Old and the Bold" is a well-known and rather popular trademark in the Estonian cultural scene. The project started as a radio show of comic sketches (by two male radio DJ-s who are not professional actors), followed by a series of TV sketches and eventually summer tours of open-air performances around the country. The film was a logical next step in the production chain, but it entailed a new challenge for the script writer, director and the two actors (the same former radio DJ-s) behind the TV serial. A much longer, more nuanced and multilayered story (compared to the TV or radio series format) had to be created for a viable feature film. And the storyline had to be comprehensible for a foreign audience as well.

The fictional world of the film models present day Estonia, the locations and landscapes are easily recognizable. So for an Estonian audience a close connection with the real space is established from the outset. There are two opposite surroundings where the action is set: the capital city of Tallinn vs. the peripheral, "in-the-middle-ofnowhere" countryside of southern Estonia. In the fictional world there are two levels (i.e. a fiction within fiction device): the level of the two radio DJ-s (that serves as the "real" in comparison with the second level) and a world created by their imagination in the live comic sketches they create through voice-acting. On the first level the characters are realistic in their appearance and behaviour. On the

14 Premiered in 2003. Script: Peep Pedmanson. Director: Rando Pettai. Cinematographer: Mait Mäekivi. 
second level the characters are qualitatively more exaggerated and stereotypical - their costumes, make up, the props (especially vehicles as lifestyle markers) mock certain genuinely existing Estonian stereotypes by developing their distinct characteristics to their extremes.

The main character of the story is Väino (Henrik Normann), who belongs to the second level of fiction and is a dedicated bachelor in his fifties, living in the capital. His misfortunes - loneliness, being evicted from his home, given a substitute house in the countryside far away from the capital - and his adaptation in the new environment form the pivot of the storyline. His feckless, reserved, misogynist behaviour mocks and enacts one of the ironic Estonian self-descriptions: "hot (i.e. passionate) Estonian men". A common conception of an Estonian male is that they are careless, lack passion, are uncomplimentary, etc. Väino's fate mirrors in an inverse way that of the radio DJ Norm (Henrik Normann), who creates Väino. Norm is a young man from the countryside who does not have a home in the city - he stays overnight in the radio studio where he works. Both men are lonely, searching for a home and secretly yearning for love. In the end, Väino gets both - he sells his unwanted rundown homestead to NATO who plans to build an airport on those lands. Afterwards Väino moves to a fancy villa (the surrounding landscape of which is unknown) with the girl he fell in love with. This resolution implies a subtle parody of an Estonian cliché: as a rule a man with a house must have a wife. Having accidentally acquired enough money, Väino literally buys the villa and in a less direct sense also buys a wife, thereby conforming to the commonplace dream cultivated by today's consumer culture. "'Home' has indeed become a marketable, exchangeable, and sentimentalised good." (Relph 1976: 83). But he does not acquire a new identity through this purchase because "home is not just the house you happen to live in" (Relph 1976: 39). Contemporary identity construction foregrounds the personality (with his/her biography, appearance, world view, etc.) that determines the home rather than the other way around. However, Väino's external signs of success work as a psychological compensation mechanism for Norm, who more or less remains a loser. "Norm" is not normal at all as the name seems to suggest, which creates a comic ambiguity.

Casting is especially significant in this film, since the two male actors play a total of six main characters. They play "themselves" on 
the first level of fiction as radio DJ-s Norm (Henrik Normann) and Mill (Madis Milling). On the second level of fiction they both impersonate one male and one female character. For the Estonian spectators both actors are generally known only through these two characters they impersonate in the TV series and in the film. Therefore there is a very strong disposition to identify the actor with this particular character, thereby creating an easily recognizable, fixed and stable role. All the devices for role creation an actor can employ to "transform" oneself into the character - use of voice, body (gestures, plastics, movement in space), mimics, make-up, costume contribute to the creation of colourful, grotesque and exaggerated types - i.e. amplified stereotypes, which in their more moderate form have a clear position in the popular self-models of the community.

The conceptual strategy of world-making that can probably first and foremost be attributed to the director, script writer and cinematographer is derived from parody. It imitates and comments on several other cultural texts and practices. The most evident targets of the parody are soap operas and sitcoms. Even the Estonian title pattern "The Old and the Bold..." is a subversive allusion to the titles of soap operas such as "The Bold and the Beautiful". Two US critics ${ }^{15}$ also easily recognize the soap opera mode, although they naturally miss the allusion in the original title, lost in the English translation. The constant presence of humour-evoking travesty or drag element (men playing women, comparable to the classical movie "Some Like It Hot") disrupts the common sitcom-type fictional world which this film would otherwise plainly imitate. It "lowers" these two popular genres even more through parody and invites the Estonian audience prone to watching sitcoms and soap operas to reconsider its attitude towards these genres and to develop a more critical spectator-relation to their daily media content.

The general theme of the film is the sensitive issue of home and more specifically the relation to the land and countryside landscape

${ }^{15}$ Barnes, Harper 2004. 'Made in Estonia' isn't quite an export quality film. PostDispatch 01/02/2004. http://newhomes.stltoday.com/stltoday/entertainment/ reviews.nsf/0/D8FB0E597F91CD6C86256E0E0018FD4F?OpenDocument\&Head line $=$ 'Made + in + Estonia' + isn't+quite + an + export + quality + film (access date: 15.10.2005); Felperin, Leslie 2003. Made In Estonia. Variety.com. December 3. http://www.variety.com/review/VE1117922555? categoryid=31\&cs=1 (access date: 15.10 .2005$)$. 
which in the stereotypical and canonical Estonian self-description is the true site of an Estonian home (i.e. a farmhouse surrounded by fields and forests) which is one of the core elements of traditional national identity. The usual direction of population movement in present-day Estonia is away from the countryside and increased suburbanization. Väino's route is exactly the opposite. This alone suffices to make him an "inverted" hero, since he, albeit unwillingly, acts against the common mentality. Still, according to the declared (but no longer lived) national identity, his return to the countryside would be a positive example. This turns him into an ambiguous hero, since most urbanized Estonians seem to long in their hearts for a true home in the countryside. Owning a house signifies a high social status in Estonia. But Väino's house is on the brink of breaking down and more a source of problems than pride.

\subsection{Lonely Hero and the Problematic Question of Home}

We now present a brief comparison of the stagings of national identities performed in "The Old and the Bold..." and "Estonian Funeral". In the former, the main character Norm/Väino is a loser, who normally evokes a distanced and ironic attitude, but due to the severity and tragedy of his problems (solitude, homelessness), a sympathetic identification with him emerges for Estonians (see Jauss 1977: 271-277). The response of the foreign audience perhaps stayed more on the ironic side. The US critics, for example, did not notice the specific issue of solitude associated with the problems of land and home. ${ }^{16}$ The fictional hero, Väino, is a survivor-type, and follows the comic life strategy; with his adaptability and ability to turn chance occasions in his own favour, he seeks to resolve his problems with a minimum of suffering (Meeker 1997: 14-15). The real character, Norm, employs a strategy of escapism, finding consolation in the fictional characters he creates for the radio-show. The protagonist of "Estonian Funeral", Andres, tends to be a rather tragic anti-hero, and in this sense he is similar to Norm. Andres is haunted by uncanny memories, surfacing from the depths of the national subconscious. As a protagonist he remains dramaturgically weak - his moralistic commentaries distance and perplex the spectators. The only perspec- 
tive he offers is an improbable wish to escape to a "far-away land where the orange trees grow", a place where there is no need to do any work. The familiar workaholics from the national stereotype remain more alive and genuine, and provoke laughter through parodic exaggerations.

In the two considered and analysed stagings, the element of traditional peasant culture is still intrinsic to the national selfdescriptions, foregrounding the deep love-and-hate relationship with the land. Relations with the homestead are central to both of these texts. The image of home presented in them is a combination of ideal and real places. "Estonian Funeral" and "The Old and the Bold..." are both informed by "geopathology", i.e. the "problem of place — and place as problem" (Chaudhuri 1995: 55), through the ruptures that occur in the character - homestead relations. In the former Andres and in the latter Norm/Väino share a similarly dislocated connection with the traditional home in the countryside. The texts loosen the sacred bonds with the homestead by applying parody as a deconstructing technique that reveals the suppressed contradictions and anxieties. Similarly, as a deconstructive critique in general, it attacks essentialist philosophical concepts (see Hall 1996a: 3-4). These stagings disclose the relativity of the taken-for-granted national values. Nevertheless this strategy does not amount to the destruction of traditional national values. It only shows their inadequacy in the contexts of rapidly changing Estonian lifestyles and the corresponding everyday lived identities.

Finally, both "Estonian Funeral" and "The Old and the Bold..." function as forms of national therapy, saturated by self-irony. They reflect the multiplicity and contradictions of Estonian identities today. It is remarkable that the creators of both artistic texts have an ethical concern - they care about the issues they stage. Therefore, the laughter that arises in the audience does not serve just an entertaining but also a cathartic function.

\section{Hybrid national identity}

In 20th century cultural theory, concepts of hybrid cultures, hybrid identity and hybridization are often associated with ethnically mixed identities, issues of linguistic mingling, etc. Hybridity has assumed a central position in postcolonial and globalization discourses, referring 
to the contact between two or more cultures (between the self and the Other) and the formation of new transcultural forms (Hall 1996b; Bhabha 1994; Young 1995). Cultural hybridization may be generally defined as a situation "when an individual or a group is exposed to and influenced by more than one cultural context" (Oyserman et al. 1998: 1607); it is linked with the adaptations people undergo while moving from one cultural context to the other.

In addition, the concept of hybridity has received theoretical treatment in cultural semiotics through an engagement of hybridity with the descriptions of interference between cultural languages. Mikhail Bakhtin, an influential figure for postcolonial theory, uses the term 'hybridization' to describe the textual encounter of two or more "consciousnesses, separated from one another by epoch, by social differentiation or by some other factor" (Bakhtin 2001: 358). Juri Lotman furthermore stresses that in order to stimulate the development and generation of new meanings in a culture, the intervention of a foreign element becomes crucial (Lotman 1991: 290-291). Hybridization (or creolization) of cultural languages consists in the process whereby the principles of one cultural language begin to model the principles of the other in spite of extensive differences between their grammars. 'Hybridization' is characteristic of periods of cultural change. Culture evolves through the stages of hybridization (creolization) and homogenization (Lotman 2002: 2652). Sooner or later hybridization ends with the formulation of a new homogeneous selfmodel of a culture.

The concept of 'hybridization' is far from being unproblematic, because once one states that "all culture is a hybrid, and hybridization is universal" (Papastergiadis 1995: 9), the concept may lose its explanatory potential. Although the postcolonial treatment of 'hybridization' focuses its attention on the colonial antagonism and inequity, the aspect of new hybrid identity, stressed by Homi Bhabha, questions the essentialist approach to culture and identity. The relationship between the colonizer and the colonized is always reciprocal and ambivalent (Bhabha 1994). In everyday life people are usually not consciously aware of the hybrid nature of the culture they live in, because internalized cultural self-descriptions stress the homogeneity of national culture, which in the case of Estonia seems to be built on a seemingly "uncorrupted core" that has remained the same in spite of multifarious foreign influences and colonisations. It should be evident 
that no national culture can identify itself without certain "others" and in an evolving dialogue partners change and influence each other mutually. We would like to stress that hybridity exists in ethnically "pure", "homogeneous" groups (e.g. Estonians) as well, and to show how different levels of hybridity relate to national identity.

Ever since its conscious cultivation, Estonian national culture has been shaped by strong influences of German and Russian culture (19th century), later also by other European and Soviet cultural models and languages. Estonian culture has undergone multiple phases of intensive hybridization and can therefore be justifiably labelled as hybrid and creole (Hennoste 2003: 92-93), although many of the borrowed and adapted elements are now considered to be genuinely Estonian.

Forming a hyphenated, ${ }^{17}$ hybrid identity allows the person to adopt an integrative acculturation strategy (cf. Berry et al. 1977: 132) that fosters active participation in the public life of the society. The official Estonian historiography has silenced the ethnic diversity for the sake of projecting a homogeneous national identity, based to a great extent on the Estonian language, which is in fact full of loans and adapted speech patterns. This protective strategy of national self-description is constantly challenged in the contemporary media environment where "interpretive communities use the media to create new, interstitial identities that are linked to "official" cultural identity, but also linked to the images culled from international film and television, and to international and regional cultural movements."(Olson 2002) In contrast to the official discourse of historians and politicians, the artists have to a greater extent dealt with the actual diverse legacy of inter-cultural influences and mixtures that underlie the lived identities of the Estonian national community today. Through this disruption of homogeneity, the dynamics of and ability to adapt flexibly with a culture are celebrated and stimulated.

\footnotetext{
17 "Hyphenated identity" refers to a specific type of ethnic identity which relies on connecting two different ethnic origins (languages or cultures or regions) and claiming to hold more or less equal allegiance to both (e.g., Latin-American, Japanese-Canadian, African-American).
} 


\section{1. "Goodbye, Vienna"18}

Because of certain historical developments, it is the Germans who have traditionally been the "hostile foreigners" for Estonians. ${ }^{19}$ The colonizing relation of German culture with Estonian culture consists of the aggressive Christian mission by the Teutonic Order (Deutscher Orden) into the present-day territories of Estonia during the 13th century, the establishment of a new administrative division here, and turning local peasants into subalterns of recently settled German landlords. The mutual but asymmetrical influence of the two cultures lasted for seven centuries. Since both Estonian and Baltic German culture evolved on a shared territory, they are both hybrid cultures. Nevertheless, national narratives created in Estonian literature and especially in national-ideologically inclined historiography have strongly supported the commonplace myth of Estonian (ethnic) culture that has preserved its ,authentic core" in spite of all the foreign influences. When the Estonian nationality was formed in the last decades of the 19th and in the beginning of the 20th century, Baltic Germans were the Other opposed two whom Estonian identity was constructed; Estonians used the colonizer's culture to create their own (Annus 2000b: 123). The Estonian national movement was initiated by Baltic German Estophiles and many national cultural forms (e.g., the foundation of numerous song, drama and literary societies, creation of national poetry, etc.) were directly created on the basis of German models. Those hybrids are nowadays unconditionally accepted as part of national culture. At the turn of the 21st century, many Estonian intellectuals have stressed the importance of German influence in the formation of Estonian culture as part of the European cultural space, and have begun research that focuses on these bilateral cultural connections, especially in literary texts (see Lukas 2004). Whereas in Estonian literature the narrative representations of Baltic Germans are quite varied, visual representations of them in theatre and film seem to be rare and relatively stereotypical.

18 Premiere: August 20, 2002, Tartu Theatre Lab. Text: Jaan Undusk. Director: Tõnu Lensment. Scenographer and costume designer: Silver Vahtre.

${ }^{19}$ In this particular context, „German” and „Estonian” are used as conventional labels for those communities that dwelt on the territories of present day Germany and Estonia and shared a common way of life, language and belief system. 
Jaan Undusk, the author of the drama "Goodbye, Vienna. (Gertrud)" (published in 1999), has a twofold position with respect to the aforementioned context. He is both a creator of fictional texts and an outstanding literary researcher who at present leads a research project that focuses on the creation of the narrative of Estonian identity. Undusk has actively studied Baltic German literary and historical heritage and wants to bring this cultural Other into the focus of attention by showing how contemporary Estonian culture has developed from this interrelationship, as well as how the waning Baltic German culture today shares a common environment with the Estonian culture. Examples of this long-established co-evolution that has formed the foundation for hybrid identities are the common Baltic solidarity and a shared land history (Undusk 2002, Undusk 2000, Undusk 1993). All these research interests are reflected in "Goodbye, Vienna". Undusk is also the translator and commentator of Friedrich Nietzsche's "Ecce homo" into Estonian, so the thematic richness of the drama can already be foreseen. "Goodbye, Vienna" was staged in august 2002 as a production of Tartu Theatre Lab (Tartu Teatrilabor), directed by Tõnu Lensment.

The fictional time-space of the drama is set in Vienna in the 1990s, more precisely in August of 1991; the premiere on the 20th of August coincided with the day the Estonian national statehood was restored. The staging took place in a multi-layered symbolic space in Tartu in the ruins of old Dome Church (built in the 13th to 16th century), originally one of the biggest gothic cathedrals in the Baltic states. The performance took place in the reconstructed chorus-part of the building, where the History Museum of the University of Tartu resides today. This building has another important role in the Baltic German and Estonian intellectual history - for more than a century it functioned as the Tartu University Library. Therefore the audience can find various strata of cultural past in this architectural space as the "condenser" of public memory (cf. Kotov 2002). In accordance with the fictional space in acts two and three (inside St. Stephens Cathedral in Vienna) the performance moves vertically from the hall to the attic of the Dome Church. At the same time the spectators feel the heightened sacredness of being surrounded by the soundscape of the church bells and organ music and the smellscape of frankincense candles. The result of the meeting of "foreign" (St. Stephens Cathedral in Vienna) and "own" (Tartu University History Museum) creates an 
estranged hybrid effect - the fictional space conjures up the latent dimension of the real space, its very primal sacral dimension.

The casting of the main roles was of utmost importance in the staging of "Goodbye, Vienna". Nietzsche was played by Tõnu Oja, an actor in his late thirties with a bohemian image, with something naturally hesitant in his behaviour. An outgrown haircut and coarse moustache emphasize his peasant-like look. Gertrud, on the other hand, is performed by Merle Palmiste, a charming actress who is dissimilar from a stereotypical Estonian woman. She is a tall brunette, with a beautiful figure, in her early thirties. Both actors are wellknown, Palmiste especially is a beloved celebrity who performs in various media.

The Estonian connection in "Goodbye, Vienna" becomes evident from the very first act, where the characters discuss their origins. At first glance, the protagonist Adolf Nietzsche seems to have nothing Estonian about him. His name is a combination of two infamous names in German history - Adolf Hitler and Friedrich Nietzsche. The trick lies in a clever anagrammatic word-play where the transformation of letters changes "Nietzsche" to "Estnische" (adj. Estonian) (Kraavi 2002). Therefore we may define Nietzsche as a "crypto-ethnic" (Hutcheon 1998: 28-33) Estonian whose name does not tell us anything about his ethnic origin. Although he is an Estonian, Nietzsche's national identity is somewhat uncertain. He is a contemporary young intellectual, a "postmodern pilgrim" — to paraphrase Zygmunt Bauman (cf. 1996: 19-23) — whose "desert" is the academic sphere and who, thanks to various scholarships, spends a considerable amount of his formation years in different (European) universities. ${ }^{20}$ But unlike for a vagabond (see Bauman 1996: 28-29), the idea of a home(land) is still important for him. We can therefore ask: is Nietzsche really even an Estonian academician, an Estonian philosopher? We can speak about asymmetric power relations between different philosophical traditions and also about a certain hybridity that emerges when foreign ideas are translated into a particular national language (culture). In today's international

20 This is an allusion to Young Estonia (1905-1915), a movement of Estonian intellectuals, the members of which declared that they are Estonians but want to become Europeans. Many of its members educated themselves in European cultural centres such as Paris, Vienna, etc. The few Estonian intellectuals before the end of the $19^{\text {th }}$ century were assimilated into the Baltic German culture. 
philosophical space, important national traditions function as empires that possess international prestige, and their peripheral colonies lack wider acknowledgement (Schusterman 1997: 297).

During the German influence, many of their ideas were adopted in Estonia, but did they move in the opposite direction as well? Do national traditions exist in philosophy at all? Two different conceptions of nationality in philosophy can be proposed - one considers national to be the particular regional institutions or organisations (e.g. universities), whereas the other seeks the more metaphysical content of a nation's way of thinking. In "Goodbye, Vienna" the question is not so much about schools of philosophy (even though there are numerous allusions to Nietzsche, Wittgenstein, etc.), but rather about philosophizing in the sense of playing with thoughts. The latter is specifically national or ethnic, because it originates from native language, it is possible only in this particular language and is untranslatable. $^{21}$

Foremost in "Goodbye, Vienna" is the linguistic space, which seems to support the belief/argument that the Estonian language forms the very basis of national identity. Most of the characters are Baltic Germans but they speak Estonian for the audience. The dramatic text is full of untranslatable wordplays. For example, the central game repeatedly reformulated by Gertrud is supported by an acoustic similarity of two words: vabadus (freedom) can at any moment turn into labasus (banality). The Sapir-Whorf hypothesis of linguistic determination is paraphrased by Gertrud when she says: "I don't understand it [Estonian], but I know that it is my mother's tongue that sits in my flesh and bones. [...] If I don't speak Estonian, then perhaps I look in Estonian, perhaps I hear and smell in Estonian?" (Undusk 1999). "Goodbye, Vienna" as a unilingual play that contains various cultural languages. Here one can find the complex philosophical discussions inspired by Nietzsche and Wittgenstein side by side with the vulgarities of everyday discourse. Both the ancient Baltic German culture and culture of young Estonian intellectuals are represented here, etc.

In 1991 it was still rather unusual for a young Estonian scholar to have a chance to study abroad. Nietzsche has only three days to spend in Vienna and he is so caught by the city that the news brought by an acquaintance, the young Baltic German countess Gertrud - "Estonia

21 We wish to thank Peeter Torop for this comment. 
is in a revolution, yesterday they declared independence" — hits his national nerve as an embarrassing surprise. He is disappointed that this historical event happened while he was away. Both Nietzsche and Gertrud are actually alien in Vienna and paradoxically they share a common homeland - Estonia (Estland). Though Gertrud has never visited Estonia, she and her relatives constantly stress that they are representatives of the "Baltic spirit". When Gertrud wants to tease Nietzsche, she calls him "a German" or "the son of a reverend". ${ }^{22}$ In this play/staging, Nietzsche is in a complicated position; he is invited to the "parlour of the Teutonic Order" where he would be forced to share both the common history and the common present with strangers (Baltic Germans) in a strange country (Austria). His host, baron von Middendorf calls the independence of Estonia "the last great event in the Baltic German history" and stresses that there would have been no national sovereignty if there had been no Baltic German barons who "embodied freedom in the Russian state". 23

22 There is a double connotation here. First, of course, Friedrich Nietzsche was the son of a minister. "Protestant reverend" in the most common sense refers to conservatism. Second, German reverends as representatives of colonizers were ambivalent persons in the history of Estonia, "culturalizing" Estonian peasants and later became interested in Estonian language and culture through translations of clerical texts. However, there is a possibility that already before the protestant reformation reached the Estonian territory, some Estonians may have become members of the clergy themselves, because theological education was the most readily available for vernacular people and served as an universal humanitarian education during those times. It is difficult to tell whether Estonian reverends were hybrid persons for other Estonians because they were now part of the culture of colonizers, or because of their position in the social hierarchy they no longer shared the grassroots position of Estonian peasants.

23 Middendorf's words once again refer to many historical aspects. It was the Baltic German community that brought the ideas of German national romanticism into Estonia in the 19th century. The Estonian national awakening movement adopted many forms of German culture, giving them a national-Estonian content. "Russian state" here signifies both the Russian Empire in the turn of the 19/20th centuries and the Soviet occupation from 1940-1991. This delicate hint is explicable only for Estonians who stayed in their homeland after World War II, satirizing those Estonians who emigrated and after the events in August 1991 overemphasized their role in restoring the independence. 


\section{2. "Agent Wild Duck",24}

Although the international title of the Estonian film "Agent Wild Duck" ("Agent Sinikael", 2002) invites an association with the parodic and comic instances of the spy thriller genre, this first impression is misleading. "Agent Wild Duck" plays with generic and narrative expectations of the spectators on several levels. Traditionally, a spy story focuses on suspense, glamour, displaying the extraordinary circumstances and assignments of undercover work, culminating in the triumph of the protagonist super-hero. In contrast to this, "Agent Wild Duck" (based on an original screenplay by Marko Raat and Andres Maimik) is an unglamorized spy movie (cf. "Spy Game", "The Bourne Identity") with practically no episodes of gun slinging or explosive action. It displays only the grim and unpleasant characteristics of living in the world of constant paranoia, lack of emotional satisfaction and mental loneliness.

Within this movie, hybridization processes operate especially vividly on the levels of world-making and character portrayal. A clear hybridization of genre-specific visual styles is discernible, since it is a feature film (fictional content, wide screen format, meticulously composed shots, the usage of markedly artificial-looking rear-projection in car driving episodes, etc.) with many sequences composed in the visual style of documentaries. However, the aesthetic of the movie is not psychologically realistic or naturalistic. It rather relies on hyperbole, subtle satire or irony, painting a mocking and sad caricature of the new economic situation and its influence on values and ethics. Western audiences may find it comfortable to categorize this film as yet another statement against globalization.

For most of the time, the world created in this film is generalized and not explicitly stated as depicting any geographically specified place in the world. There are no conspicuous visual clichés of national self-representation (e.g. landmark buildings, ethnic costumes, etc.) that would indicate a connection with a specific nation state. But in the passport check episode, the customs officer replies to the arriving antagonist Florian Flug: "Welcome to Estonia". This is a direct

24 Premiere: 2002. Script: Andres Maimik, Marko Raat. Director: Marko Raat. Cinematographer: Arko Okk. 
citation of the "Brand Estonia"25 project slogan, the process of creation of which was heavily criticized in the Estonian media as a token of government ignorance and folly in spending tax payer money. The reply sounds ridiculous, since the antagonist has just told the customs officer the purpose of his visit: "I intend to fire a bunch of workers, organize a revolt and perform a human sacrifice". However, it is strikingly well in accordance with the popular Estonian perception of bureaucratic ignorance and corruption in the state apparatus. The languages spoken, certain allusions to work ethics, social problems connected with miners, specific industrial and natural landscapes etc., signal to the Estonian audience that the setting is Estonia.

Most of the time the interiors used in the movie are stylized (espionage firm office, restaurant, protagonist's apartment), rather empty, and no ethnically marked decor is used. However, some props (e.g. second hand cars imported from the west), some of the set design (e.g. the factory director's office, furnished with standardized Soviet furniture; the Soviet style café interior in the mining region), characters and specific social problems (the reorganization of big and inefficient large-scale enterprises, illegal business deals) indicate that it is a post-soviet country, a society in transition in the second half of the 1990s. For a West-European audience it may as well be set anywhere in eastern Europe.

Intercultural influences are the main phenomenon modelled by this film - more precisely the imbalance, "explosions", unexpected developments that a sudden and strong influx of alien principles can cause in the receiving culture. The main conflict in the film unfolds between different worldviews and ethical positions which, among other dissimilarities, happen to originate from different cultures. The two main characters of the film embody two sharply contrasted ideologies of living and working. Their ideologies are already hybrids of diverse cultural sources and their clash in the fictional world creates yet another new potential for hybridization.

25 In 2001 and 2002, the Estonian governmental institution for supporting entrepreneurship - Enterprise Estonia - carried out the Brand Estonia project: a communications strategy and a visual identity was developed to promote the Republic of Estonia abroad. The strategy describes Estonia as a positively transforming country. The verbal and visual identity presented in the Estonia Style brand book is composed of a slogan, a logo, a predefined set of colours, patterns, photographs and a typeface to be used in all international media related to the country (http://www.eas.ee/). See also footnote 8 . 
The protagonist Hans Gens ${ }^{26}$ (a crypto-ethnic Estonian with a rather German-sounding name) clearly incorporates features of Soviet culture and markedly "authentic" Estonian traits as well. Hans, with his ethics that is inadequate in the new economic system, is a hybrid person, as he combines: (1) the Estonian national (self-ascribed) zeal for doing one's work with painstaking precision and fervour, devoting every aspect of one's life to work; (2) the soviet high ideal of being totally faithful and loyal to the state or organisation you are part of. Because spies did valuable service to the state during the Cold War, they could retain a very high self-esteem and consider themselves noble warriors in the vanguard of the great battle against the exploiting and greedy capitalism. Hans admires the technical perfection of Stirlitz (from the film "The Seventeen Moments of Spring"), the most celebrated spy in Soviet popular culture. Since the end of the Cold War, the former spies were forced to retrain themselves and they lost their high social prestige.

Hans was lucky: he found work in a private enterprise called Konfident Kapital, specialized in industrial espionage (publicly "advertised" under the euphemism of "PR-services"). He could continue practising his formerly highly praised professional skills, but his attempts to preserve a high self-esteem and a solid identity start to crumble away. He no longer receives positive feedback from the system and his natural inclination towards paranoia (i.e. "delusions of persecution, grandeur, and hypochondria" (Dowbiggin 2001) which are to a certain degree essential for survival in the totalitarian Soviet culture as well as for spying) gradually exacerbates to the extreme.

The psychosomatic result is narcolepsy - brief but sudden and irresistible attacks of deep sleep - caused by his work that eventually ruins his ability to do this very same work that caused it in the first place. Narcolepsy is the clinical outcome of constant suppression of emotions during leisure time, and work that is technical and stressful in its nature. Emotional reservedness is a rather stereotypical feature in the self-model of Estonians and the glorification of loyalty, as well as technical workmanship are a clear residue of the Soviet period. The protagonist is faced with the influences of this hybrid legacy on his

26 Played by a well-known and good-looking Estonian theatre actor Mait Malmsten, who has substantial experience in acting in TV series and feature films. His roles have mostly been positive ones and his appearance evokes sympathy rather than disgust in the minds of the Estonian audience. 
personal identity, as he embodies these ideals in an extreme form, while the government has to deal with them on the collective level, such as for example the problem of the miners (or any other people doing physical work), who are relatively superfluous for the new economy.

A bold and brave herald of the new economy is the "top specialist" from Germany - a "human resources consultant" Florian Flug. ${ }^{27}$ Hans is irritated by the news that the new owners are sending their own "top specialist" and asks his manager angrily: "What do the Germans want from here?" This outburst of hostility sounds slightly xenophobic and resonates fairly well with the Estonian spectator, since Germans were the colonizers and the local oppressing rulers on the Estonian territory from the 13th to the 20th century. Although there are no direct reasons that should bring about this hatred today, the painful aspects of history stay firmly in the Estonian national consciousness. The former colonizer creeps back in a new disguise to take over the higher positions of power. Hans senses a threat to his position in the company and is reluctant to changes.

Florian is also distinctly hybrid. Although his nationality is German, he does not utter a single German word. His fluent command of the international language of business — English — evinces his identity as a cosmopolitan person, a postmodern "player" (cf. Bauman 1996). His ethnic origin is not his most important feature - representing West-European superiority of economic power and know-how is. Yet this superiority is not unambiguous since in his practice of managing human resources Florian combines rationality and efficiency with magic rituals and sacrifices that he has probably adapted from some African tribes (the exact source is insignificant, what is essential is the exotic impression). This peculiar hybridization of working methods seems rather ridiculous and nonsensical for the Estonian spectator. However, none of the characters dares to protest, as Florian is labelled a "top expert" from Germany, a country famous for its highly disciplined, orderly and rational working culture. This

27 Played by the German performance artist Florian Feigl, who is unfamiliar to the film's core audience and whose appearance and face look distinctly alien compared to the other characters. Therefore F. Flug is a rather well-chosen person to play the strange foreigner. Although in the film's storyline he as the antagonist is successful, he is not endowed with the sympathy of the audience, mostly because of his alien features. 
depiction of quiet submission to crazy ideas from a figure of authority is a perspicuous critique of the Estonian serf-mentality.

The clash and contrast between the protagonist and the antagonist mainly takes place between being liberal, innovative versus being oldfashioned, conservative. Florian values the "beauty of the game", that is aesthetics, not ethics. Hans, on the other hand, values loyalty above all, a deeply ethical criterion. Florian enjoys the process and consequences of his work. For Hans, completing the mission is the only thing that matters. Emotional reactions are to be avoided and consequences are not to be considered. Florian's working methods imply interaction with and manipulation of people. Hans's methods presuppose strict avoidance of interaction, and manipulation of documents, the material carriers of information. Florian is charismatic, bold, self-confident, unpredictable - a radical. Hans is reserved, paranoiac, distrustful, ascetic, predictable and systematic - a conservative. In the age of globalisation and ensuing hybridization and dynamism, the position of Florian is superior to that of Hans, since the former is more flexible and adaptive to the ever-changing circumstances. As they are sharply contrasted opposites in the fictional world, no hybridization occurs between their character traits.

However, an intermediate and developing character is placed between them: Monika Sumberg ${ }^{28}$ (again a crypto-ethnic Estonian with a rather German sounding name). In the beginning of the story she is the "assistant" and girlfriend of Hans. In the end she inclines more towards Florian's worldview and way of life.

Since the cast of the film does not contain a single positive character there is no direct and obvious point of identification for the audience. The audience understands that Hans is noble in his ideals (and the Estonians probably recognize their own national work ethics in his professional credo), but his introverted, unemotional, reserved character (once again the exaggerated features of the Estonian male stereotype) and failure to adapt are unlikely to elicit a sympathetic identification. The antagonist, Florian, certainly does not provide a comfortable role-model either. He is too bizarre, foreign, alien for the common sense of the majority of the spectators.

The woman in the triangle, Monika, provides little possibilities for sympathetic identification as well, since she becomes obsessed with

28 Monika Sumberg is played by a young and attractive Estonian theatre actor Kersti Heinloo. 
ruthlessly climbing the career ladder. However, she is a person in transition, in change, searching for a new identity. Therefore she can function as an embodiment of the flexible, adaptive type, who can point the way out of the antagonism of ascetic ethics (Hans) and noethics (Florian). She is an ethical hybrid. She abandons the old conservative work-ethics but does not totally dispose of her humanistic concern: she still shows warmth, compassion and care for those who are not able to adapt (Hans, the miners).

The reception of "Agent Wild Duck" by the Estonian film critics was rather positive. It received the film critics award of Best Estonian Film in 2002 for its original film language, its skilful blend of sincerity and irony within its penetrating social criticism of the Estonian society today. However, the cinema audience in Estonia did not share the sentiment of the critics and the total number spectators in cinemas was around 4000 (the estimated number of spectators during the September 12, 2004 screening on Estonian Television - 54 000). From this one can infer that the treatment of identities in "Agent Wild Duck" has not had a significant actual influence on the lived identities of most Estonians. However, its potential was clearly recognized on the metalevel of culture (i.e. critical appreciation).

\subsection{Different Pasts Integrate with Various Presents}

Neither of these two texts explicitly foregrounds being Estonian or Estonianness, yet our analysis points to a way national identity can be interpreted in these texts in the context of intercultural influences and globalization. The possibility of finding and describing hybrid identities created by the stage production "Goodbye, Vienna" and the film "Agent Wild Duck" shows that hybridity is an emergent topic in the present-day Estonian cultural self-models. The protagonists of both texts find themselves in a transformational situation where their hitherto well-functioning identities no longer provide them with security and balance. Both protagonists are unsuccessful in adapting to new circumstances that should actually coerce them to change their self-models. Unconsciously they apprehend the need to change, since they are no longer certain where they belong. They therefore start to contemplate their identification possibilities, but in practice fail to change. Instead, adherence to fixed values and in-grown behavioural 
patterns makes them modernist heroes cast into the vortex of the progressing postmodern turn.

Both protagonists are aware of their hybrid nature, where many foreign influences have fused together with the national ones, but they keep their status quo, unwilling to change in spite of the changing situation surrounding them. Therefore, they both can be called local hybrids, whose personal identity is structured around the specific combination of historically conditioned values stemming from (currently or historically) adjacent, overlapping cultural spheres that have spread only in this particular border area. The changing sociocultural environment nevertheless forces them to deal with their identity. Hans is rooted in Estonian work ethics on the one hand, and Soviet loyalty to the organization on the other; this makes him a local hybrid who cannot easily be relocated someplace else. Nietzsche is an Estonian who does not realize how pervasive the influence of Baltic German culture has been on the development of contemporary Estonia. Despite being a knowledgeable intellectual, aware of the global influences on local culture, he subconsciously seems to believe in the mythological concept of a nation. Adolf Nietzsche's situation - an urgent need to (re)define his national identity while being abroad - is quite typical.

"Agent Wild Duck" seems to tackle problems of a more universal scope, capturing some essential insights into the process of globalisation, but it does so through a staging of the local cultural context of Estonia. The colonial history of Estonia, the extreme protestant work ethic (that has a well known intimate connection with the spirit of capitalism that still functions as the driving force behind global trends) and smallness of the nation, inducing a strong fear of extinction, are mobilised for this purpose. These three elements foster the domination of a rather reactionary and conservative conception of national identity among Estonians.

This inability for substantial changes exists side-by-side with the new, dynamic, daringly hybrid identities. Gertrud in "Goodbye, Vienna" and Florian in "Agent Wild Duck" represent the identities of postmodern players (Bauman 1996) for whom the connection with their home environment is less significant than for local hybrids. It should be noted that global hybrids in the analysed stagings are not ethnic Estonians. Florian's personal identity is structured around values that originate from many spatially non-adjacent cultures and 
therefore as a combination seems much more random, contingent and also liable to change more easily. Two highly dissimilar cultural contexts meet and intermingle in Gertrud - the Baltic German nobility and the proletarian Vienna mixed with Catholicism; and even though she is unable to articulate it properly, she senses that her roots are in Estonia. Nevertheless, she is a contemporary urbanised woman who enjoys playing with her identities, never adopting a single one for long.

Between the local and the global hybrid a third type - transitional hybrid - can be distinguished. S/he almost never reaches the global end of the spectrum since breaking the local ties is not so easily accomplished. Monika Sumberg is an example of such type, being somewhere in-between the two aforementioned hybrids. This transitional hybridity seems to be an emerging reality of new personal and national identities in Estonia.

To sum up, both stagings present the hybrid nature of Estonian national identity by focusing on basic interferences between German and Estonian as well as Soviet Russian and Estonian culture. In addition, both deal with the changes in national identity in the context of globalization, indicating various forms of cultural hybridity that may exist. Problems such as the protestant work ethic versus the postmodern playful attitude towards work, the theme of nationality in philosophy, the dubious nature of Estonian language and ethnicity as the main components of national identity, are acutely raised in these stagings.

\section{Conclusions}

The essentialist conception, stressing the stable core of a homogenous national identity, is today replaced by constructivist approaches that emphasize the plurality of national identities. Nevertheless, the transforming national identities are not entirely novel and do not irretrievably replace historical components of national identity. Some elements of national past (history, myths, artistic narratives) are always mobilized for the creation of future visions of national identity.. The former core elements can be renegotiated from a contemporary viewpoint and emerging national identities, likewise, cannot entirely replace the pre-existing ones, some common con- 
nectors of national memory are needed for the new national identities to be vigorous.

Estonian national identity has traditionally relied on cultural heritage (language, folk tradition, etc.) and the self-model of Estonians has been relatively fixed from the 1940s due to its functioning as a tool of resistance against the assimilation strategies of foreign occupations. Theatre as live and therefore not completely censorable art functioned as a substitute for free media in Estonia, and many films, that on first sight do not include any rebellious content for the foreign spectator, likewise carried coded messages, displaying national values and national heroes for Estonians themselves. In such oppressive circumstances, mainly homogenous self-models appeared on stage and on screen. During the past fifteen years of Estonian political independence, democratic society, and integration into European Union, the possibilities for self-models have multiplied tremendously. Today, fixed, simplified and outdated national identities are in a process of transformation, intensively carried out in the arts, where both the presentation and reflection of self-models can be performed. The analyses of stagings of national identities in Estonian theatre and film in this paper were written from an internal viewpoint and can be seen as a study of auto-communication within the national community, which is an essential precondition of the communication between different nations. Such a study of national identities can help us elucidate both of these forms of communication more appropriately.

Ever since the national awakening, literature has been the leading field of Estonian national culture, therefore it is characteristic that new national identities of the postmodern kind (such as the playful, the ironic, the parodied) first emerged there. However, theatre, and later film as well, have in parallel been significant loci where national identities find concrete audiovisual and embodied manifestations, set to the stage for public reflection and evaluation. The creation, maintenance and development of national identities in all cultural spheres always involves a process of staging, comprising of three sub-processes, namely setting on stage, performing and perceiving/interpreting. Although theatre and film primarily create aesthetic stagings, they can also be considered cultural stagings due to their collective nature, as they provide a nation with the opportunity for public estimation of their declared and lived collective identities. In comparison with literature, where the creation process is first of all individual, 
theatre and film stagings are produced cooperatively, relying on collective memory. This may help explain the reasons why traditional historical components of national identity are still intrinsic in the stagings of the past few years. Hence, theatre and film can be considered as transitional forms, where individual and collective stagings of national identities coalesce. Live and favourable reception of certain identities presented in theatre and film stagings prove that they have found a response in the audience's collective memory, where the same aspects of national identity may be well-established.

Stagings of national identity can be realised in various genres, the most solemn of them being historical drama. Contemporary Estonian audience, however, seems to find the comic representations of national identity more enjoyable, though this does not mean that only simplified amusement is offered by those theatre performances and films. The majority of the stagings examined in the present paper were hilarious and bewildering reinterpretations of national themes, that at the same time had a rather anxious and even a tragic tonality. The analysis supported our hypotheses about two possible strategies of changing national identities in contemporary Estonia - deconstruction and hybridization.

Deconstruction was conceived of primarily as an intellectual strategy for interpreting canonical texts and self-models of a nation. The theatre production "Estonian funeral" (2002) and the film "The Old and the Bold Get on Their Feet" (2003) were comedies that applied deconstructive methods, such as parody, irony, travesty and slapstick humour to re-interpret traditional, conservative self-models of Estonians that exist within the imagined community and in classical texts of Estonian literature. However, the deconstruction presented here was not a strategy of annihilation, but rather the questioning of traditional values and convictions by provoking the audience's reflexive laughter. Some key elements of the traditional national selfmodel (for instance, devotion to physical work, having a home in the countryside, being a resisting/suffering hero) are playfully re-contextualized, highlighting their constructedness and fictionality. In the traditional self-model, Estonians are defined by modesty, emotional reservedness, solitude, conservativeness. These qualities are not highly praised in any of the analysed texts; instead, a critical attitude is expressed through parodying or treating them with irony. Concurrently, new aspects of national identity - the enjoyment of life, a 
modern home in the city, a successfully transforming hero - are presented. It is probably not incidental that actors from the younger generation, local celebrities known from television and other media, were primarily cast into the main roles, proposing new role-models for identification for the audience. Nevertheless, the protagonists in the deconstructive, as well as in hybrid stagings remain ambivalent, they are rather antiheroes, evoking sympathy but not admiration.

In addition to the diversity and contradictions brought out by the deconstructive strategy, the homogeneous self-model is called into question in a similar way by acknowledging and exhibiting hybridity as part of the Estonians' lived national identities. "Goodbye, Vienna" (2002) in theatre and "Agent Wild Duck" (2002) in film staged various types of hybridizations, namely an intermingling of the colonizing German culture and the colonized Estonian culture; an amalgam of opposite mentalities (the inner exile of a Soviet citizen and the openness of a representative of an independent nation); a combination of aesthetic and ethical values. In the process of hybridization, elements from the periphery of national identity move to the centre and vice versa. Borderline places and outsiders are presented, that do not qualify for the perfect image of a nation. The stagings showed us deserted and decaying rural homesteads, under-inhabited small towns and desolate industrial landscapes together with their marginalised inhabitants, such as Russian-speaking miners, unemployed alcoholics, criminals, etc. The hybridization of national identity brings new characters to the stage who embody postmodern identities: a local hybrid identity (Adolf, Hans), a global hybrid identity (Gertrud, Florian), a transitional hybrid identity (Monika). The frequent occurrence of foreign-sounding names hints at the latently hybrid nature of Estonians and the Estonian language, the most central element in the declared self-model of Estonians. In the two films (and in Estonian cinematography in general) several foreign and colonizing languages (mostly Russian, German, English) are used in addition to Estonian. This vividly represents the reality of lived identities in contemporary Estonia: fluency in one or several foreign languages is a prerequisite for being successful in Estonia, although on the declared identity level, the mastery the Estonian language defines "authentic" Estonianness.

In conclusion, deconstructed and hybrid national identities introduced in the present paper are not as much new identity types but 
rather strategies of creating possibilities for new identities to emerge; they indicate that existing self-models should change. Lived national identities are always in the process of transformation and in certain periods of their development a critical self-reflection is needed. The latter can be realised through the deconstruction of existing values, myths, symbols, etc. Hybridization, alike, is an inherent quality of national identity, primarily existing latently, and is brought into the collective consciousness only during periods of active reflexivity and, thereby, identity transformation. Deconstruction and hybridization as identity strategies help us understand that national identities are not disappearing in the contemporary world, but are rather being reformed, and show us how these strategies, inherent to the postmodern attitude, do not completely eliminate the traditional aspects of national identity but re-contextualise, re-examine and re-evaluate them. Questions about home, and what and where it is, and how much of our past influences our future, are still acute and painful. Playing with national identities in Estonia has just begun, and all the possibilities are open... ${ }^{29}$

\section{References}

Anderson, Benedict 1983. Imagined Communities: Reflections on the Origin and Spread of Nationalism. New York: Verso.

Annus, Epp 2000a. Postmodernism kui hilissotsialismi kultuuriloogika. Keel ja Kirjandus 11: 769-780.

- 2000b. National mythology: Past and present. Interlitteraria 5: 115-130.

Bakhtin, Mikhail 2001. The Dialogic Imagination: Four Essays. (Holquist, Michael; Emerson, Caryl, trans.) Austin: University of Texas Press.

Barthes, Roland 1957. Mythologies. Paris: Seuil.

Bauman, Zygmunt 1996. From pilgrim to tourist — or a short history of identity.

In: Hall, Stuart; du Gay, Paul (eds.), Questions of Cultural Identity. London: Sage, 18-36.

Berry, John W.; Kalin, Rudolf; Taylor, Donald M. 1977. Multiculturalism and Ethnic Attitudes in Canada. Ottawa: Minister of Supply and Services Canada. Bhabha, Homi 1990. Nation and narration. London: Routledge.

- 1994. The Location of Culture. London: Routledge.

Billig, Michael 1995. Banal Nationalism. London: Sage Publications Ltd.

29 The research leading to the publication of this paper was supported by grant ETF5313 (Identity of Cultural Texts and Creolization of Cultural Languages) from the Estonian Science Foundation. 
Binder, Beate; Kaschuba, Wolfgang; Niedermüller, Peter (eds.) 2001. Inszenierung des Nationalen. Geschichte, Kultur und die Politik der Identitäten am Ende des 20. Jahrhunderts. Köln: Böhlau Verlag.

Calhoun, Craig 1998. Social theory and the politics of identiy. In: Calhoun, Craig (ed.), Social Theory and the Politics of Identiy. Oxford: Blackwell, 9-36.

Carlson, Marvin 1994. Nationalism and the romantic drama in Europe In: Gillespie, Gerald (ed.), Romantic Drama. Amsterdam: John Benjamins Publishing Co., 139-152.

Chauduri, Una 1995. Staging Place: The Geography of Modern Drama. Ann Arbor: University of Michigan Press.

Cohen, Anthony P. 1993. Culture as identity: An anthropologist's view. New Literary History 24: 195-209.

Culler, Jonathan D. 1983. On Deconstruction: Theory and Criticism After Structuralism. New York: Cornell University Press.

Dentith, Simon 2000. Parody. London: Routledge.

Dowbiggin, Ian 1999. Suspicious Minds: The Triumph of Paranoia in Everyday Life. Toronto: Macfarlane, Walter \& Ross.

Eco, Umberto 1990. The Limits of Interpretation. Bloomington: Indiana University Press.

Edensor, Tim 2002. National Identity, Popular Culture and Everyday Life. Oxford: Berg.

Esslin, Martin 1987. The Field of Drama: How the Signs of Drama Create Meaning on Stage and Screen. London: Methuen.

Fischer-Lichte, Erika 1992. The Semiotics of Theater. (Gaines, Jeremy; Jones, Doris L., trans.) Bloomington: Indiana University Press.

- 2004. Einleitung: Theatralität als kulturelles Modell. In: Fischer-Lichte, Erika; Horn, Christian; Umathum, Sandra; Warstat, Matthias (eds.), Theatralität als Modell in den Kulturwissenschaften. Tübingen: Francke Verlag.

Friedman, Jonathan 1994. Cultural Identity and Global Process. London: Sage.

Früchtl, Josef; Zimmermann, Jörg 2001. Ästhetik der Inszenierung: Dimensionen eines gesellschaftlichen, individuellen und kulturellen Phänomens. Frankfurt am Main: Suhrkamp.

Gellner, Ernest 1983. Nations and nationalism. Oxford: Blackwell.

Goffman, Erving 1959. The presentation of self in everyday life. New York: Doubleday.

Hall, Stuart 1994. Cultural identity and diaspora. In: Williams, Patrick; Chrisman, Laura (eds.), Colonial Discourse and Post-Colonial Theory: A Reader. Harlow: Pearson Education.

— 1996a. Introduction: Who needs identity? In: Hall, Stuart; du Gay, Paul (eds.), Questions of Cultural Identity. London: Sage, 1-17.

- 1996b. New ethnicities. In: Morley, David; Chen, Kuan-Hsing (eds.), Stuart Hall: Critical Dialogues in Cultural Studies. London: Routledge, 441-449.

Hennoste, Tiit 2003. Postkolonialism ja Eesti: Väga väike leksikon. Vikerkaar 45: $85-100$.

Hutcheon, Linda 1998. Crypto-ethnicity. PMLA 113(1): 28-33. 
Jauss, Hans Robert 1991. Ästhetische Erfahrung und literarische Hermeneutik. Frankfurt am Main: Suhrkamp.

Kivirähk, Andrus 2002. Papagoide päevad: Näidendid. Tallinn: Eesti Keele Sihtasutus.

Kotov, Kaie 2002. Semiotic condensers in cityspace. (Paper delivered at the conference Place and Location III, Tallinn, September 19-21, 2002.) Manuscript.

- 2005. Kultuur, identiteet ja enesekirjeldus. Acta Semiotica Estica II. Tartu: Tartu University Press, 184-192.

Kraavi, Janek 2002. Eestlane Nietzsche. Eesti Ekspress, Areen 14.08.

Lotman, Juri 1967 = Лотман, Ю. М. Тезисы к проблеме "Искусство в ряду моделирующих систем". Sign Systems Studies (Tруды по знаковым системам) 3: 130-145.

- 1990. Universe of the Mind: A Semiotic Theory of Culture. (Shukman, Ann, trans.) London: I. B. Tauris.

- 1991. Kultuurisemiootika : tekst - kirjandus - kultuur. Tallinn: Olion.

- 1992 = Лотман, Ю. М., Культура и взрыв. Москва: Гнозис

- 2002. Kultuuri fenomen. (Salupere, Silvi, trans.) Akadeemia 14(12): 2644 2662.

Meeker, Joseph 1997. The Comedy of Survival: Literary Ecology and a Play Ethic. Tucson: University of Arizona Press.

Mäkinen, Helka; Wilmer, Steve E.; Worthen, W. B. (eds.) 2001. Theatre, History, and National Identities. Helsinki: Helsinki University Press.

Müller-Doohm, Stephan; Neumann-Braun, Klaus (eds.) 1995. Kulturinszenierungen. Frankfurt am Main: Suhrkamp.

Norris, Christopher 2003 [1991]. Deconstruction: Theory and Practice. London: Routledge.

Olson, Scott Robert 2002. Contaminations and hybrids: Indigenous identity and resistance to global media. Studies in Media \& Information Literacy Education 2(2): article no. $19 .^{30}$

Oyserman, Daphna; Sakamoto, Izumi, Lauffer, Armand 1998. Cultural accommodation: Hybridity and the framing of social obligation. Journal of Personality and Social Psychology 74(6), 1606-1618.

Pavis, Patrice 1992. Theatre at the Crossroads of Culture. (Kruger, Loren, trans.) London: Routledge.

Porter, Dilwyn; Smith, Adrian (eds.) 2004. Sport and National Identity in the Post-war World. London: Routledge.

Pretes, Michael 2003. Tourism and nationalism. Annals of Tourism Research 30(1): 125-142.

Relph, Edward 1976. Place and Placelessness. London: Pion Limited.

Ruby, Jay 2000. Picturing Culture. Explorations of Film and Anthropology. Chicago: University of Chicago Press.

Schusterman, Richard 1997. Internationalism in philosophy: Models, motives and problems. Metaphilosophy 28(4): 289-301.

$30 \mathrm{http}: / / \mathrm{www} . u t p r e s s . u t o r o n t o . c a / j o u r n a l / e j o u r n a l s /$ simile (access date:

15.10.2005). 
Sevänen, Erkki 2004. The study of cultural identity: development and background of a multi-disciplinary field of research. In: Kupiainen, Jari; Sevänen, Erkki; Stotesbury, John A. (eds.), Cultural Identity in Transition: Contemporary Conditions, Practices and Politics of a Global Phenomenon. New Delhi: Atlantic Publishers \& Distributors, 33-63.

Smith, Anthony D. 1991. National Identity. Reno: University of Nevada Press.

- 2000. Images of the nation: Cinema, art and national identity. In: Hjort, Mette; MacKenzie, Scott (eds.), Cinema \& Nation. London: Routledge, 45-59.

Thompson, Andrew (2001) Nations, national identities and human agency: putting people back into nations. The Sociological Review 49(1): 18-32.

Toro, Fernando de 1988. Towards a socio-semiotic theory of theatre. Semiotica 72(1/2): 37-70.

Undusk, Jaan 1993. Baltisaksa kirjandus: tegu ja tekst. Vikerkaar 8(10): 26-31.

- 1999. Goodbye, Vienna (Gertrud). Vikerkaar 14(8/9): 3-81.

- 2000. Ajalootõde ja metahistoorilised žestid: Eesti ajaloo mitmest moralist. Tuna 2: 114-130.

- 2002. Eesti ajaloo kotkaperspektiivist. Minu vaidlus Brüggemanniga. Tuna 3: 99-116.

Vellerand, Lilian 2003. Sissevaade Eesti Draamateatri 2002.aastasse. Teatrielu 2002: 132-144.

Viires, Piret 2004. Traces of the postmodern world in the 21st-century Estonian novel. Interlitteraria 9: 130-139.

Willems, Herbert; Jurga, Martin (eds). 1998. Die Inszenierungsgesellshaft. Opladen: Westdeutscher Verlag.

Wilmer, Steve E. 2002. Theatre, Society and the Nation: Staging American Identities. Cambridge: Cambridge University Press.

Young, Robert 1995. Colonial Desire: Hybridity in Theory, Culture and Race. London: Routledge.

\section{Репрезентация темы национальной самоидентификации в современном эстонском кино и театре}

Статья сосредоточивается на способах репрезентации (постановки/ экранизации) национального идентитета в эстонском театре и кино последних лет. Целью является дополнить общепризнанные трактовки национальности (Anderson 1983; Gellner 1983; Bhabha 1990), которые зачастую недооценивают роль театра и кино в образовании национального самосознания.

Понятие национального идентитета требует в наше время комплексного подхода и точной формулировки в зависимости от контекста, в котором его употребляют. Мы определяем современный национальный идентитет как динамическое понятие, выделяя его 
связь с этническим идентитетом, указывая на различия “реального” и декларируемого идентитета, а также на особенности национального идентитета, обоснованного культурой. Говоря о национальном идентитете как о постановке, мы исходим при использовании понятия "постановка" (staging) как из его эстетического значения, которое охватывает различные уровни и средства творческого процесса, так и из его культурологического значения, в котором при помощи понятия постановки описываются процессы культуры, в которых нечто ставится определенным образом на "социальную сцену" для публичной рефлексии.

Объектами анализа нами были выбраны четыре поставноки два фильма ("Made in Эстония", “Агент Кряква") и две театральные постановки (“Эстонские похороны", “Goodbye, Vienna”), которые вышли на экраны/на сцену в 2002-2003 гг. Результаты анализа подтвердили нашу гипотезу о возникновении новых национальных идентитетов в пространстве эстонской культуры, указывая в то же время и на то обстоятельство, что ad hoc созданные понятия деконструированный и гибридный национальный идентитет являются не столько новыми типами идентитета, сколько стратегиями идентификационного процесса, которые позволяют образовываться новым идентитетам. Деконструированный национальный идентитет указывает на высокую степень саморефлексии, когда доминирующие в данный момент элементы национального идентитета пересматриваются, заново контекстуализируются и переоцениваются. А понятие гибридного национального идентитета позволяет объяснить диверситет национального идентитета и сосуществование в нем различных компонентов. Обе стратегии постановки национального идентитета характерны прежде всего периодам трансформации национального идентитета, подтверждая тем самым, что гомогенная постановка национального идентитета заменяется репрезентацией нескольких новых авто-моделей.

\section{Rahvuslike identiteetide lavastamine kaasaegses eesti teatris ja filmis}

Artikkel keskendub rahvusliku identiteedi lavastamise viisidele eesti filmis ja teatris viimastel aastatel. Meie eesmärgiks on täiendada üldaktsepteeritud rahvusluse-käsitlusi (Anderson 1983; Gellner 1983; Bhabha 1990), milles sageli alahinnatakse teatri ja filmi rolli rahvusluse kujundajatena. 
Rahvusliku identiteedi mõiste vajab tänapäeval kompleksset lähenemist ja täpset defineerimist sõltuvalt kontekstist, milles seda kasutatakse. Määratleme kaasaegset rahvuslikku identiteeti dünaamilisena, tuues välja selle seosed etnilise identiteediga ja juhtides tähelepanu elatud ja deklareeritud identiteetide erinevustele, samuti kultuuripõhise rahvusliku identiteedi eripärale.

Rääkides rahvuslikust identiteedist kui lavastusest, lähtume lavastamise (staging) mõiste puhul nii selle esteetilisest tähendusest, mis hõlmab endas loomeprotsessi erinevaid tasandeid ja vahendeid, kui ka kultuuriteoreetilisest tähendusest, milles lavastamise mõiste abil kirjeldatakse kultuuriprotsesse, milles miski seatakse teatud viisil "sotsiaalsele lavale" avalikuks reflektsiooniks.

Artikli analüüsi osas uurime me rahvusliku identiteedi lavastamist mõlemas eelmainitud tähenduses. Analüüsi objektiks valisime neli lavastust — kaks filmi ("Vanad ja kobedad saavad jalad alla", "Agent Sinikael") ja kaks teatrilavastust ("Eesti matus", "Goodbye, Vienna"), mis esietendusid/linastusid aastatel 2002-2003. Analüüsi tulemused kinnitasid meie hüpoteesi uute rahvuslike identiteetide esilekerkimise osas Eesti kultuuriruumis, osutades samas ka sellele, et ad hoc mõisted dekonstrueeritud ja hübriidne rahvuslik identiteet ei ole mitte niivõrd uued identiteeditüübid, kuivõrd idenditeediprotsessi strateegiad, mis võimaldavad uutel identiteetidel välja kujuneda. Dekonstrueeritud rahvuslik identiteet viitab kõrgele eneserefleksiivuse astmele, milles parajasti domineerivad rahvusliku identiteedi elemendid üle vaadatakse, uuesti kontekstualiseeritakse ja ümber hinnatakse. Hübriidne rahvuslik identiteet aga võimaldab selgitada rahvusliku identiteedi diversiteeti ja erinevate komponentide kooseksisteerimist selles. Mõlemad identiteedi lavastamise strateegiad on iseloomulikud eeskätt rahvusliku identiteedi transformatsiooniperioodidele, kinnitades, et rahvusliku identiteedi homogeenne lavastus asendatakse mitmete uute enesemudelite lavaletoomisega. 